\title{
The kind of pollination and ability to parthenocarpy of pepino (Solanum muricatum Ait.)
}

\author{
Katarzyna Kowalczyk \\ Department of Vegetable and Medicinal Plants \\ Warsaw University of Life Sciences \\ Nowoursynowska 159, 02-776 Warsaw, Poland \\ e-mail: k_kowalczyk@sggw.pl
}

Key words: clone, self-pollination, cross-pollination, emasculation

\begin{abstract}
The objective of the research was to assess a grade of parthenocarpic fruit and fruitsetting following cross-pollination and self-pollination in pepino plants (Solanum muricatum Ait.). An experiment with six pepino clones of different origin was set up in glasshouse conditions. Experimental clones were subjected to the following treatments: self-pollination, cross-pollination, and emasculation without any control. The tested clones of pepino were self-pollinated, capable of cross pollination and facultative parthenocarpic. The differences between clones in their ability to parthenocarpic fruit formation were observed. The ripening period of pepino fruits and their weight depended on a clone.
\end{abstract}




\section{INTRODUCTION}

Pepino fruit contains a lot of ascorbic acid (20-60 mg\%) and mineral salts (Ahumada and Cantwell 1996, Anderson et al. 1996, Rubatzky and Yamaguchi 1997). It also shows diuretic and refreshing properties. The taste and smell of the fruit recalls these of a melon and mango (Shiota et al. 1988). Due to the growing interest in exotic fruits, studies on introduction of the species into commercial production are being conducted in many countries. The plant is characterized by variable yielding, resulting from poor fruitsetting. Ruiz and Nuez (2000), for the most part, consider Solanum muricatum self-pollinated species. However, its pollination biology has not been thoroughly studied yet.

The objective of the research was to assess a grade of parthenocarpy and fruit setting after cross-pollination and self-pollination in pepino plants.

\section{MATERIAL AND METHODS}

In order to study the phenomenon of parthenocarpy and possibilities of artificial pollination, an experiment with six pepino clones of different genotype and origin was set up in glasshouse conditions in 1999. Clones from New Zeland were marked 1 to 5, a clone from Israel was numbered 6. Softwood cuttings derived from a tested clones' mother plants were rooted in perlite for 14 days and then planted in plastic cylinders of $8 \mathrm{~cm}$ diameter, filled with peat substrate. In March 1999 , rooted plants were transferred to their final position on rockwool slabs, at density of 5 plants per square meter. Plants were fertilized according to recommendations for tomato, grown on the same type of substrate. Plants were grown for a single stem and three clusters where each was pruned to three fruits per truss. Experimental clones had been subjected to the following treatments:

- Self-pollination - a flower cluster had been isolated before blooming with the use of a special insulator made of cellophane. Each flower was pollinated several times during blossoming, using clone-specific pollen.

- Cross-pollination - at the phase preceding anthesis, flower buds were deprived of anthers. Then clusters were covered with a special insulator and each flower was pollinated with pollen of a different clone. For cross-pollination, pollen of the clones showing the highest germinating vigor was used (Kowalczyk et al. 2001). Flowers of clones 1 and 6 were pollinated with pollen of clone 3 , flowers of clones 2, 4 and 5 with pollen of clone 1 and flowers of clone 3 with pollen of clone 6 .

- Emasculation - anthers had been removed from flower buds before pollen release, and then a cluster was covered with an insulator.

- Control - this group of plants was not subjected to any special treatments. 
Two-factorial experiment was set in eight replications, each with four plants, in a randomized blocks design. A kind of plants treatment which was applied on all flowers in each cluster constituted the first factor, while a clone the second one. The period measured from blossoming to harvesting in full ripe stage of pepino fruit (yellow skin) as well as the weight of fruits were recorded for each studied clone. For fruits from particular combinations a percentage of seeded fruits was estimated.

For the analysis of variance, Anova program was applied and Tukey test was used to show which values differed significantly at $p=0.05$.

\section{RESULTS}

The time that passed from blossoming to reaching harvest ripeness depended on a clone. Fruits of clones 3 and 6 ripened earliest, within 77 and 81.5 days from blossoming respectively. Fruits of clone 1 needed as much as 106 days (Fig. 1). The clones differed significantly in fruit weight similarly as in previous studies by Kowalczyk and Kobryń (2000). The biggest fruits, of mean weight 398.2 g, were collected from clone 3. Lesser weight had been gained by fruits of clone 4 (303.7 g on average). The mean weight for fruits of clones 1,2,5 and 6 ranged from $161.1 \mathrm{~g}$ to $229.8 \mathrm{~g}$ (Table 1). The fruits of a higher mean weight were obtained as a result of self-pollination and cross-pollination, comparing to the control and emasculation. However, a significant impact of such treatments was noted only for clones 4 and 6 (Table 1). Owing to self-pollination and cross-pollination of pepino flowers, seeded fruits were obtained. Fruits collected both from plants from which flower buds had been deprived of anthers and from control plants were parthenocarpic (Table 2). The highest number of fruits with seeds obtained after self-pollination was collected from clones 3 and 6 , constituting 80.0 and $77.1 \%$ respectively. In clone 1 only $23.2 \%$ of fruits were seeded, whereas in clones 2,4 , and 5 all fruits were parthenocarpic (Table 2). The highest fraction of seeded fruits, obtained after cross-pollination, was observed for clones $6(78.6 \%)$ and $3(59.3 \%)$, the lowest for clone 5 (only 6.4\%). In all clones, both from the control and emasculated flowers, $100 \%$ of parthenocarpic fruits were obtained (Table 2). 
Table 1. The mean weight of pepino fruit $(\mathrm{g})$ depending on clone and plants treatment

\begin{tabular}{lccccccc}
\hline & \multicolumn{7}{c}{ Number of clone } \\
\cline { 2 - 7 } Treatment & 1 & 2 & 3 & 4 & 5 & 6 & Mean \\
\hline Self-pollination & 149.7 & 233.1 & 448.6 & $359.9 \mathrm{a}^{*}$ & 213.8 & $256.9 \mathrm{a}$ & $277.0 \mathrm{a}$ \\
Cross-pollination & 171.3 & 251.2 & 384.6 & $443.9 \mathrm{a}$ & 203.8 & $263.1 \mathrm{a}$ & $286.3 \mathrm{a}$ \\
Emasculation & 159.3 & 198.6 & 360.2 & $202.1 \mathrm{~b}$ & 224.1 & $206.9 \mathrm{ab}$ & $225.2 \mathrm{~b}$ \\
Control & 176.0 & 236.4 & 399.4 & $209.0 \mathrm{~b}$ & 187.4 & $142.1 \mathrm{~b}$ & $225.1 \mathrm{~b}$ \\
\hline \multirow{2}{*}{ Mean } & n.s. & n.s. & n.s. & & n.s. & & \\
\hline & $164.1 \mathrm{a}$ & $229.8 \mathrm{a}$ & $398.2 \mathrm{c}$ & $303.7 \mathrm{~b}$ & $207.3 \mathrm{a}$ & $217.2 \mathrm{a}$ & \\
\cline { 2 - 6 } & & & & & & & \\
\end{tabular}

n.s. - no significant

*Values marked with the same letter do not differ significantly at $\mathrm{p}=0.05$

Table 2. The percentage of seeded pepino fruit depending on clone and plants treatment

\begin{tabular}{lcccccc}
\hline & \multicolumn{7}{c}{ Number of clone } \\
\cline { 2 - 7 } Treatment & 1 & 2 & 3 & 4 & 5 & 6 \\
\hline Self-pollination & $23.2 \mathrm{a}^{*}$ & $0 \mathrm{a}$ & $80.0 \mathrm{a}$ & $0 \mathrm{a}$ & $0 \mathrm{a}$ & $77.1 \mathrm{a}$ \\
Cross-pollination & $30.6 \mathrm{a}$ & $19.7 \mathrm{~b}$ & $59.3 \mathrm{a}$ & $21.9 \mathrm{~b}$ & $6.4 \mathrm{~b}$ & $78.6 \mathrm{a}$ \\
Emasculation & $0 \mathrm{~b}$ & $0 \mathrm{a}$ & $0 \mathrm{~b}$ & $0 \mathrm{a}$ & $0 \mathrm{a}$ & $0 \mathrm{~b}$ \\
Control & $0 \mathrm{~b}$ & $0 \mathrm{a}$ & $0 \mathrm{~b}$ & $0 \mathrm{a}$ & $0 \mathrm{a}$ & $0 \mathrm{~b}$ \\
\hline
\end{tabular}

*Values marked with the same letter do not differ significantly at $p=0.05$

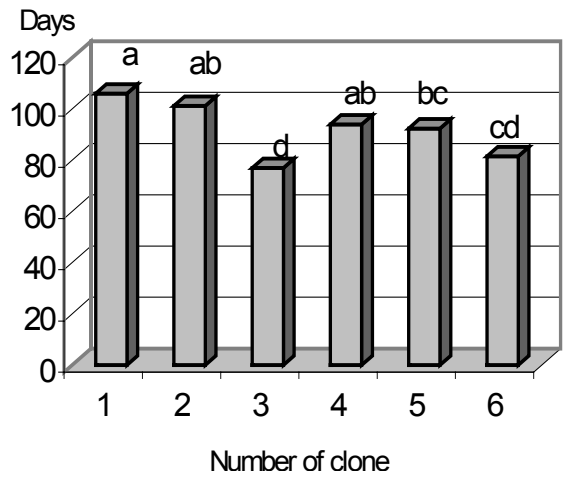

Fig. 1. The time from blossoming to reaching harvest ripeness of fruit of pepino clones *Values marked with the same letter do not differ significantly at $p=0.05$ 


\section{DISCUSSION}

The biology of reproduction in pepino is still under-explored. According to Mione and Anderson (1992) and Murray et al. (1992) pepino is self-compatible and selfpollinated, however, its presumed wild ancestor Solanum caripense is strongly selfincompatible. Ruiz and Nuez (2000) consider Solanum muricatum for a selfpollinated species, for the most part. Tests on germination of pollen grains of the clones studied in the present work, carried out by Kopcińska et al. (2002 a) demonstrated that pollen tube penetrates into the ovule both under self-pollination and cross-pollination conditions. Therefore, the clones were acknowledged selfpollinated, self-compatible and capable of cross-pollinating. In the present work, seeded fruits were obtained after self-pollination and cross-pollination of the clones. The absence of seeds observed in the fruits obtained after self-pollination of clones 2,4 , and 5 probably resulted from low germination capacity of their pollen and in the case of clone 4 additionally from too high temperature occurred during cultivation what was presented by the studies of Kowalczyk et al. (2001) and Kopcińska et al. (2002 b). Many authors (Grigg et al. 1988, Ercan and Akilli 1996, Ruiz et al. 1996) highlight the fact that pollen vitality varies greatly and depends on different environmental factors, mainly on temperature which, when exceeds $30^{\circ} \mathrm{C}$, can lead to its decrease. In spite of the lack of pollination barriers, the compared clones demonstrated a strong tendency to set parthenocarpic fruits. Flowers deprived of anthers and then left unpollinated, yielded up parthenocarpic fruits in all clones. In the control clones with no additional treatment applied, $100 \%$ of parthenocarpic fruits were also observed. Similar results were obtained by Prohens et al. (1998) and Welles (1992). On the other hand Burge (1989) obtained 66\% seedless fruits in pepino plants free of any treatments. According to Murray et al. (1992), parthenocarpy is obligatory and determined by male sterility of some clones of pepino, while in others it is facultative, and seeded fruits are set as a result of successful pollination. Parthenocarpic genotypes can yield exclusively seeded fruits, providing their flowers had been pollinated (Burge 1989). On the other hand, without pollination, non-parthenocarpic clones can set some seedless fruits - occasional parthenocarpy (Murray et al. 1992; Ruiz et al. 2000). The obtained results show that the investigated clones are facultative parthenocarpic. Facultative parthenocarpy also occurs in tomato and other plants, in which mechanisms of pollination and fertilization are strongly determined by precise environmental conditions (Georg et al. 1984). Parthenocarpy is particularly required in a production of these plants which, in response to adverse cultivation conditions, show poor fruit set. The facultative character of the phenomenon enables successful cultivation of such plants. The use of parthenocarpic pepino clones, not requiring pollination for fruit setting, can enable obtaining high yield despite conditions adverse for fruit formation (Prohens et al. 1998). 


\section{CONCLUSIONS}

- Tested clones of pepino were self-pollinated, capable of cross pollination and facultative parthenocarpic.

- Differences between clones in the ability to parthenocarpic fruit formation were observed.

- The ripening period of pepino fruits and their weight depended on a clone.

- Parthenocarpic fruit of pepino displayed lower weight, comparing to those obtained in the course of pollination.

\section{REFERENCES}

Ahumada M., Cantwell M., 1996. Postharvest studies on pepino dulce (Solanum muricatum Ait.): Maturity at harvest and storage behavior. Postharv. Biol. Technol. 7: 129-136.

ANDERSON G.J., JANSEN R.K., KIM Y., 1996. The origin and relationships of the pepino, Solanum muricatum (Solanaceae): DNA restriction fragment evidence. Econ. Bot. 50(4): 369-380.

BURGE G.K., 1989. Fruit set in the pepino (Solanum muricatum Ait.). Sci. Hort. 41: 63-68.

ERCAN N., AKILLI M., 1996. Reasons for parthenocarpy and the effects of various hormone treatments on fruit set in pepino (Solanum muricatum Ait.) Sci. Hort. 66: 141-147.

GeORG W.L., ScotT J.W., SPlitTstoesSeR W.E., 1984. Parthenocarpy in tomato. Hort. Rev. 6: 65-84.

Grigg F.D.W., Smith P.R., Stenersen M.A., Murray B.G., 1988. Variable pollen fertility and abnormal chromosome behavior in the pepino (Solanum muricatum Ait., Solanaceae). Sci. Hort. 35: 259-268.

KOPCIŃSKA J., ŁOTOCKA B., KOWALCZYK K., KOBRYŃ J., 2002 a. Flower organs of Solanum muricatum Aiton. I. Perianth and stamen. Acta Biol. Cracov., Ser. Bot. 44: 125-134.

KOPCIŃSKA J., ŁOTOCKA B., KOWALCZYK K., KOBRYŃ J., 2002 b. Flower organs of Solanum muricatum Aiton. II. Pistil. Acta Biol. Cracov., Ser. Bot. 44: 135-143.

KOWALCZYK K., KOBRYŃ J., 2000. Effect of plant training and hormone treatment of pepino (Solanum muricatum Aiton) on the yield and fruit quality in rockwool production. Roczn. AR Poznań 423, Ogr. 31(1): 343-349. 
KowAlCZYK K., KobryŃ J., RAKOCZY TROJANOWSKA M., 2001. Comparison of pollen fertility of some pepino clones (Solanum muricatum Aiton) in different growing periods. Folia Hort. 13/1A: 309-314.

Mione T., ANDERSON G.J., 1992. Pollen-ovule ratios and breeding system evolution in Solanum section Basarthrum (Solanaceae). Am. J. Bot. 79: 279-287.

MuRRAY B.G., HAMMET K.R., GRIGG F.D.W., 1992. Seed set and breeding system in the pepino (Solanum muricatum Aiton), Solanaceae. Sci. Hort. 49: 83-92.

Prohens J., RUIZ J.J., NUEZ F., 1998. The inheritance of parthenocarpy and associated traits in pepino. J. Amer. Soc. Hort. Sci. 123: 376-380.

RUBATZKY J., YAMAGUCHI M., 1997. World Vegetables: principles, production and nutritive values. ITP Int., Thomson Publishing: 569.

RUIZ J.J., NUEZ F., 2000. High temperatures and parthenocarpic fruit set: Misunderstandings about the pepino breeding system. J. Hort. Sci. Biotechnol. 75(2): 161-166.

RUIZ J.J., PROHENS J., NUEZ F., 1996. Efecto de la temprtatura sobre el cuajado y maduracion de frutos en pepino dulce. Actas de Horticultura 14: 109-118.

ShiOTA H., Young H., PETERSON J., IRIE M., 1988. Volatile aroma constituents of pepino fruit. J. Sci. Food Agr. 43: 343-354.

WELLES G.W.H., 1992. Experiences with growing and consumer appreciation of pepino fruits (Solanum muricatum) in the Netherlands. Acta Hort. 318: 211-212.

\section{SPOSÓB ZAPYLANIA I ZDOLNOŚĆ DO PARTENOKARPII U PEPINO (SOLANUM MURICATUM AIT.)}

Streszczenie: Badano zdolność roślin pepino (Solanum muricatum Ait.) do zawiązywania owoców w wyniku partenokarpii, zapylenia krzyżowego oraz samozapylenia. Doświadczenie prowadzono w warunkach szklarniowych. Obserwacji dokonano na roślinach sześciu klonów pepino o różnym pochodzeniu. Testowane, samopylne klony pepino były zdolne do zapylenia krzyżowego oraz fakultatywnie partenokarpiczne. Stwierdzono różnice między badanymi klonami w zdolności do zawiązywania owoców w wyniku partenokarpii. Również okres osiagnięcia dojrzałości zbiorczej owoców oraz ich masa były zależne od klonu pepino. 